\title{
PIEZO1 wt Allele
}

National Cancer Institute

\section{Source}

National Cancer Institute. PIEZO1 wt Allele. NCI Thesaurus. Code C106084.

Human PIEZO1 wild-type allele is located in the vicinity of $16 q 24.3$ and is approximately $70 \mathrm{~kb}$ in length. This allele, which encodes piezo-type mechanosensitive ion channel component 1 protein, is involved in mechanically regulated ion transport. 